ACTA UNIVERSITATIS WRATISLAVIENSIS

PRZEGLĄD PRAWA I ADMINISTRACJI CXX/2

WROCŁAW 2020

https://doi.org/10.19195/0137-1134.120.66

\author{
JERZY SKORUPKA \\ ORCID: 0000-0002-6123-5538 \\ Uniwersytet Wrocławski \\ Katedra Postępowania Karnego
}

\title{
STANDARD DOSTĘPU DO INFORMACJI O PODSTAWIE DOWODOWEJ TYMCZASOWEGO ARESZTOWANIA W PRAWIE UNII EUROPEJSKIEJ I PRAWIE POLSKIM*
}

\begin{abstract}
Abstrakt: Autor analizuje zgodność obowiązujących przepisów polskiego kodeksu postępowania karnego dotyczących dostępu do ,akt aresztowych” z przepisami dyrektywy Parlamentu Europejskiego i Rady 2012/13/UE z dnia 22 maja 2012 roku w sprawie prawa do informacji w postępowaniu karnym. Oceniając polskie regulacje proceduralne, autor stwierdza, że nie spełniają one warunków określonych w wymienionej dyrektywie. Przepisy prawa polskiego dopuszczają możliwość oparcia decyzji sądu o zastosowaniu lub przedłużeniu tymczasowego aresztowania na dowodach mających istotne znaczenie dla podjęcia takiej decyzji, które nie zostały ujawnione podejrzanemu i jego obrońcy. Konsekwencją jest pozbawienie podejrzanego i jego obrońcy możliwości kwestionowania dowodów przedstawionych sądowi przez prokuratora. Powoduje to, że postępowanie sądowe w przedmiocie tymczasowego aresztowania pozbawione jest równości broni, a tym samym jest nierzetelne.
\end{abstract}

Słowa kluczowe: proces karny, równość broni, tymczasowe aresztowanie, dostęp do akt postępowania przygotowawczego

1. Celem opracowania jest ustalenie, czy standard dostępu do informacji o podstawie dowodowej tymczasowego aresztowania w prawie polskim jest zgodny z unijnym standardem dostępu do ,akt aresztowych" określonym w dyrektywie Parlamentu Europejskiego i Rady 2012/13/UE z dnia 22 maja 2012 roku w sprawie prawa do informacji w postępowaniu karnym (dalej: dyrektywa).

* Tekst powstał w ramach projektu badawczego NCN 2017/27/B/HS5/00854. W niniejszym opracowaniu wykorzystałem swój wcześniejszy tekst pt. Access to detainees' files in the light of directive 2012/13/eu of the european parliament and of the council of 22 may 2012 on the right to information in criminal proceedings and under polish law, opublikowany w „Ius Novum” 2017, nr 2, s. 126-139. 
2. W polskim piśmiennictwie prawniczym oraz orzecznictwie polskich sądów i trybunałów wskazuje się, że postępowanie w przedmiocie tymczasowego aresztowania powinno być prowadzone według zasady równości stron. Obie strony tego postępowania, to jest oskarżony i prokurator, powinni mieć takie same informacje o dowodach stanowiących podstawę decyzji o zastosowaniu lub przedłużeniu tego środka. Dlatego oskarżony powinien mieć możliwość zapoznania się z treścią dowodów wskazanych we wniosku o zastosowanie lub przedłużenie tymczasowego aresztowania, a także mieć świadomość istnienia dowodów dla niego niekorzystnych i realną możliwość odniesienia się do nich. W związku z tym informacje ważne z punktu widzenia oceny legalności aresztowania danej osoby należy udostępnić we właściwy sposób oskarżonemu i jego obrońcy. Zasadą powinna być wewnętrzna jawność materiałów, które mają istotne znaczenie dla efektywnego podważenia zasadności tymczasowego aresztowania ${ }^{1}$. W razie zainicjowania przez prokuratora postępowania w przedmiocie zastosowania lub przedłużenia tymczasowego aresztowania oskarżony, którego dotyczy ten środek, ma więc prawo do wglądu do części akt postępowania przygotowawczego, zawierającej dowody stanowiące uzasadnienie wniosku prokuratora ${ }^{2}$.

W polskim piśmiennictwie prawniczym wskazuje się, że zgodnie ze standardem wypracowanym przez Europejski Trybunał Praw Człowieka (dalej: ETPCz) na tle art. 5 ust. 4 Konwencji o ochronie praw człowieka i podstawowych wolności (dalej: EKPC) procedura kontroli zasadności i legalności pozbawienia wolności powinna być przeprowadzona z zachowaniem podstawowych gwarancji rze-

1 Zob. P. Kardas, Z problematyki dostępu do akt sprawy w postępowaniu o wyrażenie zgody na pociagnięcie sędziego do odpowiedzialności karnej, [w:] Nauki penalne wobec współczesnej przestępczości. Księga jubileuszowa z okazji 70. rocznicy urodzin Profesora Andrzeja Gaberle, red. K. Krajewski, Warszawa 2007, s. 205; P. Wiliński, Odmowa dostępu do akt sprawy w postępowaniu przygotowawczym, Prok. i Pr. 2006, nr 11, s. 74; P. Kardas, P. Wiliński, O niekonstytucyjności odmowy dostępu do akt sprawy w postepowaniu w przedmiocie tymczasowego aresztowania, „Palestra" 2008, nr 7-8, s. 23; P. Karlik, Stosowanie środków zapobiegawczych w projekcie nowelizacji kodeksu postępowania karnego, [w:] Kontradyktoryjność w polskim procesie karnym, red. P. Wiliński, Warszawa 2013, s. 353; A. Tęcza-Paciorek, K. Wróblewski, Skutki wyroku Trybunatu Konstytucyjnego z dnia 3 czerwca 2008 r., sygn. akt K 42/07 dla realizacji prawa podejrzanego do obrony w postepowaniu $w$ przedmiocie zastosowania tymczasowego aresztowania $w$ świetle art. 156 § 5a k.p.k., ,Ius Novum” 2011, nr 3, s. 36-54.

2 Zob. P. Kardas, Uprawnienia obrony do wgladu w akta postępowania przygotowawczego $w$ toku procedury habeas corpus. Rzecz o obstrukcji organów wymiaru sprawiedliwości, CzPKiNP 2009, z. 3, s. 164; idem, Standard rzetelnego procesu a prawo wgladu do akt sprawy w postepowaniu $w$ przedmiocie tymczasowego aresztowania, czyli historia jednej nowelizacji, Prok. i Pr. 2010, nr 1-2, s. 89-113; P. Hofmański, Dostęp do akt postępowania przygotowawczego. Uwagi na tle nowelizacji art. 156 k.p.k., [w:] Węzłowe problemy prawa karnego, kryminologii i polityki kryminalnej. Ksiega pamiatkowa ofiarowana Profesorowi Andrzejowi Markowi, red. V. Konarska-Wrzosek, J. Lachowski, J. Wójcikiewicz, Warszawa 2010, s. 576; D. Sokołowska, Konwencyjny i konstytucyjny standard rzetelnego procesu $w$ ramach postepowania typu habeas corpus $w$ świetle uregulowań kodeksu postępowania karnego, „Internetowy Przegląd Prawniczy TBSP UJ” 2016, nr 2, s. 132. 
telnego procesu, w tym powinna mieć sądowy i kontradyktoryjny charakter oraz powinna respektować zasadę równości broni. Powinna więc zostać zapewniona formalna równość stron przez zapewnienie im równego udziału w postępowaniu aresztowym oraz równość w dostępie do akt sprawy, w której doszło do pozbawienia wolności, w celu umożliwienia im skutecznego podważania argumentów przemawiających za zastosowaniem tymczasowego aresztowania. W konsekwencji informacja, która jest ważna w ocenie legalności i zasadności tymczasowego aresztowania, powinna być zawsze udostępniona obrońcy ${ }^{3}$. Kontrolując postanowienie w przedmiocie tymczasowego aresztowania, sąd ma obowiązek oceny, czy odmowa dostępu do akt śledztwa nie narusza fundamentalnego prawa osoby tymczasowo aresztowanej do realnej możliwości kontroli zasadności pozbawienia wolności ${ }^{4}$.

Tożsamy pogląd wyraził Trybunał Konstytucyjny w wyroku z dnia 3 czerwca 2008 roku, K 42/07, orzekając o zgodności z Konstytucją RP przepisu art. $156 \S 5$ k.p.k. ${ }^{5}$ Zakres akt udostępnianych aresztowanemu i jego obrońcy powinien być wyznaczany przez efektywność prawa do obrony. Jawne muszą być więc wszystkie te materiały postępowania przygotowawczego, które uzasadniają wniosek prokuratora o zastosowanie lub przedłużenie tymczasowego aresztowania. W razie wystąpienia przez prokuratora $\mathrm{z}$ wnioskiem o zastosowanie lub przedłużenie tymczasowego aresztowania „oskarżony [...] ma prawo wglądu do materiałów postępowania przygotowawczego (do tej części akt), które stanowią uzasadnienie wniosku prokuratora". Także Sąd Najwyższy uznał, że wnosząc o zastosowanie lub przedłużenie tymczasowego aresztowania, prokurator powinien zagwarantować oskarżonemu lub jego obrońcy zapoznanie się przynajmniej z tą częścią akt postępowania przygotowawczego, która zawiera materiały mające uzasadniać wniosek, ponieważ wymaga tego realność prawa do obrony ${ }^{6}$.

${ }^{3}$ Zob. M.Wąsek-Wiaderek, Dostęp do akt sprawy oskarżonego tymczasowo aresztowanego i jego obrońcy w postępowaniu przygotowawczym - standard europejski a prawo polskie, „Palestra” 2003, z. 3-4, s. 56-59; S. Steinborn, Dostęp obrony do akt postępowania przygotowawczego w związu z procedura habeas corpus - standard strasburski i jego realizacja w polskim procesie karnym, [w:] Problemy wymiaru sprawiedliwości karnej. Księga jubileuszowa Profesora Jana Skupińskiego, red. A. Błachnio-Parzych et al., Warszawa 2013, s. 528-537; J. Skorupka, W kwestii dostępu tymczasowo aresztowanego do wniosku w przedmiocie tymczasowego aresztowania oraz do akt sprawy w postępowaniu przygotowawczym na marginesie orzeczeń sądów powszechnych, „Palestra” 2008, nr 7-8, s. 39; M. Rusinek, O dostepie do akt postepowania przygotowawczego de lege ferenda, CzPKiNP 2008, z. 2, s. 97.

${ }^{4}$ Zob. postanowienie SA we Wrocławiu z 23 sierpnia 2007 roku, II AKz 412/07, LEX nr 301497.

5 OTK-A 2008, nr 5, poz. 77; Dz.U. Nr 100, poz. 648.

6 Zob. postanowienie SN z 11 marca 2008 roku, WZ 9/08, OSNKW 2008, nr 7, poz. 55 z aprobującą glosą W. Grzeszczyka, Prok. i Pr. 2009, nr 1. 
Należy też zauważyć, że wiedza o dowodach zebranych w sprawie jest jednym z elementów wyznaczających granice działań obrończych oskarżonego ${ }^{7}$. Prowadzenie obrony w sposób efektywny i skuteczny dla oskarżonego wymaga otrzymania odpowiedniej informacji procesowej. Bez tego utrudnione, a nawet niemożliwe będzie podjęcie decyzji co do tego, kiedy i jakie działania obrończe należy przeprowadzić. Możliwość sprawowania realnej (efektywnej) obrony $\mathrm{w}$ postępowaniu w przedmiocie tymczasowego aresztowania uzależniona jest zatem między innymi od posiadania informacji o dowodach wskazujących na popełnienie przez oskarżonego zarzuconego mu przestępstwa oraz okoliczności wskazujących na obawę bezprawnego utrudniania przez niego prowadzonego postępowania. Zasób tych informacji limituje sprawowanie przez oskarżonego obrony na etapie postępowania aresztowego. Dostęp do akt postępowania przygotowawczego w części zawierającej dowody tworzące podstawę tymczasowego aresztowana ma zatem dla oskarżonego i jego obrońcy duże znaczenie.

3. Unijny standard dostępu do informacji o podstawie dowodowej tymczasowego aresztowania określony został w dyrektywie Parlamentu Europejskiego i Rady 2012/13/UE z dnia 22 maja 2012 roku w sprawie prawa do informacji w postępowaniu karnym. Należy podkreślić, że dyrektywa jest elementem działań Unii Europejskiej zmierzających do utrzymania i rozwoju przestrzeni wolności, bezpieczeństwa i sprawiedliwości, w tym wdrożenia zasady wzajemnego uznawania orzeczeń w sprawach karnych, zakładającej, że państwa członkowskie Unii Europejskiej mają wzajemne zaufanie do swoich systemów wymiaru sprawiedliwości w sprawach karnych. Zakres tej zasady, a tym samym poziom wzajemnego uznawania orzeczeń w sprawach karnych, uzależniony jest między innymi od mechanizmów gwarancyjnych dotyczących ustanowienia i przestrzegania praw oskarżonego (rozumianego w szerokim, materialnym znaczeniu) w procesie karnym. Konieczność utrzymania i pogłębiania wzajemnego zaufania pomiędzy państwami Unii Europejskiej wynika między innymi z postanowień art. $47 \mathrm{i}$ art. 48 ust. 2 Karty praw podstawowych Unii Europejskiej (dalej: KPP) dotyczących prawa do rzetelnego procesu sądowego i prawa do obrony oraz art. 5 i 6 EKPC dotyczących prawa do wolności i bezpieczeństwa osobistego oraz prawa do rzetelnego procesu sądowego.

Dyrektywa 2012/13/UE ustanawia — z myślą o zwiększeniu wzajemnego zaufania między państwami członkowskimi — wspólne normy minimalne, które mają być stosowane w odniesieniu do informowania osób oskarżonych o popełnienie przestępstwa o przysługujących im prawach oraz o treści przedstawionych zarzutów. Dyrektywa opiera się na prawach określonych w art. 6, 47 i $48 \mathrm{KPP}$ oraz na art. 5 i art. 6 EKPC, które powinny być interpretowane zgodnie z wykładnią ETPCz. Dyrektywa znajduje zastosowanie do osób oskarżonych bez względu na ich status prawny, obywatelstwo czy narodowość, a pojęcie „oskarżenie” powinno

7 Zob. J. Skorupka, Granice prawa do obrony i dziatań obrończych w procesie karnym, [w:] Etyka adwokacka a kontradyktoryjny proces karny, red. J. Giezek, P. Kardas, Warszawa 2015, s. 98. 
być rozumiane w sposób użyty w art. 6 ust. 1 EKPC i orzecznictwie ETPCz, to jest materialnie, a nie formalnie. Dyrektywa 2012/13/UE ma wszak zastosowanie od chwili podjęcia ścigania danej osoby przez właściwe organy państwa członkowskiego, a nie formalnego przedstawienia zarzutu popełnienia przestępstwa, aż do czasu zakończenia postępowania rozumianego jako ostateczne rozstrzygnięcie kwestii, czy takie osoby popełniły przestępstwo.

Zgodnie $\mathrm{z}$ art. 7 dyrektywy $\mathrm{w}$ razie zatrzymania lub aresztowania na jakimkolwiek etapie postępowania karnego należy zapewnić osobom zatrzymanym lub ich obrońcom dostęp do będących w posiadaniu właściwych organów dokumentów, które są związane z konkretną sprawą i mają istotne znaczenie dla skutecznego zakwestionowania legalności zatrzymania lub aresztowania. Dokumenty, a także zdjęcia, nagrania audio i wideo, które są konieczne do skutecznego zakwestionowania legalności pozbawienia wolności tych osób, należy udostępnić im lub ich obrońcom najpóźniej przed skierowaniem do sądu właściwego wniosku, w celu oceny legalności zatrzymania lub aresztowania zgodnie z art. 5 ust. 4 EKPC, oraz w odpowiednim czasie, aby umożliwić skuteczne wykonywanie prawa do zakwestionowania legalności zatrzymania lub aresztowania.

Osobom oskarżonym lub ich obrońcom należy też zapewnić dostęp przynajmniej do całego materiału dowodowego będącego w posiadaniu właściwych organów, niezależnie od tego, czy jest on dla nich korzystny, czy niekorzystny, w celu zagwarantowania rzetelnego postępowania i możliwości przygotowania obrony. Dostęp do wymienionego materiału dowodowego powinien być zapewniany w odpowiednim czasie, pozwalającym na skuteczne wykonywanie prawa do obrony, a najpóźniej w chwili przekazania do sądu wniosku o zastosowanie tymczasowego aresztowania. Jeżeli organy ścigania wejdą w posiadanie dalszego materiału dowodowego, należy zapewnić dostęp do niego w odpowiednim czasie, aby umożliwić jego wykorzystanie przez oskarżonego i obrońcę.

Według omawianej dyrektywy na zasadzie wyjątku, o ile nie narusza to prawa do rzetelnego procesu, można odmówić dostępu do niektórych materiałów, jeżeli może to doprowadzić do poważnego zagrożenia życia lub praw podstawowych innej osoby lub jeżeli taka odmowa jest bezwzględnie konieczna do ochrony ważnego interesu publicznego, na przykład gdy dostęp mógłby zaszkodzić prowadzonemu śledztwu lub poważnie zaszkodzić bezpieczeństwu państwa członkowskiego, w którym toczy się postępowanie karne. Decyzja o odmowie dostępu do niektórych materiałów powinna być podjęta przez organ sądowy lub przynajmniej podlegać kontroli sądowej. Każdą decyzję odmowną należy wyważyć w świetle prawa do obrony oskarżonego, uwzględniając różne etapy postępowania karnego. Ograniczenia takiego dostępu należy interpretować rygorystycznie i zgodnie z prawem do rzetelnego procesu, określonym w art. 6 EKPC, w sposób rozumiany zgodnie z orzecznictwie ETPCz. Ponadto oskarżony oraz jego obrońca powinni mieć prawo do zakwestionowania odmowy udzielenia informacji lub ujawnienia niektórych materiałów sprawy. 
Z art. 7 dyrektywy wynika zatem, że przesłanką odmówienia dostępu do części akt postępowania przygotowawczego (niektórych dowodów) jest poważne zagrożenie życia lub praw podstawowych jednostki oraz bezwzględna konieczność ochrony ważnego interesu publicznego. Dostępu do części dowodów można odmówić w w yjątk ow y m w y a a ku, gdy okoliczności sprawy wskazują na poważne zagrożenie wymienionych dóbr prawnych oraz występuje bezwzględna konieczności ochrony ważnego interesu publicznego. Decyzja o odmowie dostępu do części akt sprawy w związku z zatrzymaniem lub tymczasowym aresztowaniem powinna być podjęta przez organ sądowy, a co najmniej, w razie podjęcia takiej decyzji, oskarżonemu i jego obrońcy powinno przysługiwać prawo do zaskarżenia takiej decyzji do sądu. Warunkiem zaskarżenia wymienionej decyzji do sądu jest świadomość odmowy dostępu do niektórych materiałów sprawy, co wymaga poinformowania o tym fakcie oskarżonego i jego obrońcy.

4. Ze względu na konieczność interpretowania przepisów dyrektywy 2012/13/ UE w sposób zgodny z orzecznictwem Trybunału w Strasburgu należy przypomnieć, że ETPCz w wyroku z dnia 25 czerwca 2002 roku w sprawie Migoń przeciwko Polsce ${ }^{8}$, powołując się na zasadę „równości broni” między stronami, to jest prokuratorem i osobą aresztowaną, podkreślił, że co prawda

ograniczony dostęp do akt sprawy w zakresie, jaki potrzebny jest do zagwarantowania aresztowanemu możliwości skutecznego zakwestionowania dowodu, na którym oparta była decyzja o zastosowaniu aresztu tymczasowego, może być w pewnych przypadkach przewidziany w postępowaniu dotyczącym kontroli przez sąd zgodności aresztu z prawem. Niemniej, ze względu na istotny ujemny wpływ pozbawienia wolności na fundamentalne prawa jednostki, postępowanie prowadzone na podstawie art. 5 ust. 4 Konwencji [...] powinno w zasadzie odpowiadać, w najszerszym, jak to jest tylko możliwe zakresie wyznaczonym przez okoliczności toczącego się śledztwa, podstawowym wymogom rzetelnego procesu, takim jak prawo do procesu kontradyktoryjnego. Chodzi o to, aby oskarżony tymczasowo aresztowany był świadomy istnienia dowodów niekorzystnych dla niego i miał rzeczywistą możliwość odniesienia się do nich.

W cytowanym wyroku ETPCz, odnosząc się do kwestii udostępniania akt postępowania przygotowawczego, stwierdził też, że z potrzeby zagwarantowania przeprowadzenia skutecznego śledztwa może wynikać konieczność utrzymania w tajemnicy części zebranych informacji w celu zapobieżenia wpływaniu na dowody przez oskarżonych i zakłócaniu przebiegu procesu. „Jednakże, ów słuszny skądinąd cel nie może zostać osiągnięty kosztem istotnych ograniczeń prawa do obrony. W związku z tym informacje ważne z punktu widzenia oceny zgodności z prawem aresztowania danej osoby należy udostępnić we właściwy sposób obrońcy oskarżonemu". Identyczne stanowisko wyraził ETPCz w decyzji

8 Wyrok ETPC z 25 czerwca 2002 roku, 24244/94 Migoń v. Polska, LEX nr 53649. Zob. też B. Gronowska, Wyrok Europejskiego Trybunału Praw Człowieka w Strasburgu z dnia 25 czerwca 2002 r. w sprawie Migoń przeciwko Polsce (dot. gwarancji procesowych dla osoby tymczasowo aresztowanej), Prok. i Pr. 2002, nr 12, s. 143. 
34091/96 z 28 stycznia 2003 roku w sprawie M.B. przeciwko Polsce ${ }^{9}$, Piechowicz przeciwko Polsce ${ }^{10}$, a także w sprawach Chruścińskiego ${ }^{11}$, Laszkiewicza ${ }^{12}$ i Dochnala ${ }^{13}$.

W innym orzeczeniu ETPCz stwierdził, że uprawnienie do wyjawienia wszystkich dowodów nie jest prawem absolutnym. W każdym postępowaniu karnym mogą pojawić się konkurujące (z wymienionym wyżej uprawnieniem) interesy, takie jak bezpieczeństwo narodowe, potrzeba ochrony świadków przed ryzykiem odwetu bądź utrzymania w tajemnicy policyjnych metod prowadzenia śledztwa, które to interesy muszą zostać przeciwstawione prawom oskarżonego. Dlatego w niektórych sprawach niezbędne może okazać się odmówienie udzielenia dostępu obronie do pewnej części materiału dowodowego, aby chronić podstawowe prawa innej jednostki lub ważny interes publiczny. Akceptowane mogą być jednak tylko takie środki ograniczające prawa obrony, które są bezwzględnie konieczne ${ }^{14}$.

Przedstawione orzeczenia dają podstawę do wniosku, że ETPCz nie wymaga udostępnienia tymczasowo aresztowanemu całości materiałów postępowania przygotowawczego. Jednak oskarżony i jego obrońca powinni mieć dostęp do akt takiego postępowania w zakresie niezbędnym do efektywnego podważenia zasadności i legalności aresztowania ${ }^{15}$. Stanowisko to znajduje uzasadnienie także w wyroku ETPCz w sprawie Lamy przeciwko Belgii ${ }^{16}$. Stwierdzono w nim, że umożliwienie skutecznego kwestionowania twierdzeń lub poglądów, które oskarżenie opiera na dokumentach znajdujących się w aktach sprawy, w niektórych wypadkach może wymagać zagwarantowania obronie dostępu do tych dokumentów ${ }^{17}$. Natomiast w sprawach Garcia Alva przeciwko Niemcom ${ }^{18}$, Lietzow prze-

9 LEX nr 74761.

10 Zob. § 203 i 204 wyroku ETPCz z 17 kwietnia 2012 roku w sprawie 20071/07 Piechowicz przeciwko Polsce, LEX nr 1147973.

11 Zob. wyrok ETPCz z 6 listopada 2007 roku w sprawie 22755/04 Chruściński przeciwko Polsce, www.echr.coe.int.

12 Zob. wyrok ETPCz z 15 stycznia 2008 roku w sprawie 28481/03 Laszkiewicz przeciwko Polsce, Legalis nr 195219.

13 Zob. wyrok ETPCz z 18 września 2012 roku w sprawie 31622/07 Dochnal przeciwko Polsce, LEX nr 1217521.

${ }^{14}$ Zob. wyrok ETPCz z 16 lutego 2000 roku w sprawie 27052/95 Jasper v. Wielka Brytania, LEX nr 76902; oraz wyrok ETPCz z 16 lutego 2000 roku w sprawie 28901/95 Rowe i Davis v. Wielka Brytania, LEX nr 76903.

15 Por. M. Wąsek-Wiaderek, Zasada równości stron w polskim procesie karnym w perspektywie porównawczej, Kraków 2003, s. 199.

16 Wyrok ETPCz z 30 marca 1989 roku w sprawie 10444/83 Lamy przeciwko Belgii.

17 Podobnie wyrok ETPCz z 22 czerwca 2004 roku, nr 29687/96 Wesolowski v. Polska, Biuletyn Biura Informacji Rady Europy 2004/3/117.

18 Wyrok ETPCz z 13 lutego 2001 roku, LEX nr 76281; Legalis nr 134653. 
ciwko Niemcom ${ }^{19}$ i Schöps przeciwko Niemcom ${ }^{20}$ ETPCz przyjął, że nie gwarantuje „równości broni” postępowanie, w którym obrońca aresztowanego nie ma dostępu do tych dokumentów znajdujących się w aktach sprawy, które mają istotne znaczenie dla efektywnego podważania zasadności tymczasowego aresztowania oskarżonego ${ }^{21}$. W sprawie Garcia Alva przeciwko Niemcom Trybunał w Strasburgu zwrócił uwagę, że dla sądu decydującego o przedłużeniu tymczasowego aresztowania istotne znaczenie miały przede wszystkim zeznania świadka, który wcześniej był już karany i przeciwko któremu prowadzone było kolejne postępowanie o przemyt narkotyków. Tymczasem obronie uniemożliwiono zapoznanie się z tymi zeznaniami i podważenie ich wiarygodności, co przesądziło o nierzetelności postępowania i naruszeniu zasady równości broni. To stanowisko ETPCz podtrzymał w sprawie Mooren przeciwko Niemcom ${ }^{22}$, ponownie wskazując, że informacje, które są ważne do oceny legalności i zasadności tymczasowego aresztowania, powinny zostać we właściwy sposób udostępnione obrońcy oskarżonego.

ETPCz nie neguje zatem potrzeby utrzymania w tajemnicy przed obroną pewnych informacji i dowodów zgromadzonych w postępowaniu przygotowawczym. Dostrzega, że potrzeba przeprowadzenia skutecznego postępowania przygotowawczego może wymagać utajnienia części informacji zebranych w jego trakcie w celu uniemożliwienia oskarżonemu manipulowania dowodami oraz destabilizowania przebiegu procesu sądowego. ETPCz jednak konsekwentnie podkreśla, że cel w postaci ochrony dobra tego postępowania nie może być osiągnięty kos ztem istotnego ograniczenia prawa do obrony. Z tego względu informacje ważne do oceny zasadności i legalności tymczasowego aresztowania powinny zostać we właściwy sposób udostępnione obrońcy oskarżonego. Wykluczone jest całkowite pozbawienie obrony dostępu do materiałów uzasadniających tymczasowe aresztowanie. Jeżeli pełny dostęp do akt sprawy jest niemożliwy, trudności z tego wynikłe powinny być zrekompensowane w taki sposób, aby oskarżony miał możliwość efektywnego kwestionowania stawianych mu zarzutów ${ }^{23}$.

Tożsamy pogląd wyraził Niemiecki Federalny Sąd Konstytucyjny, mianowicie że uszczuplenie gwarancji procesowej w postaci dostępu do akt stawia organy prowadzące postępowanie przygotowawcze w uprzywilejowanej sytuacji, wynikającej z tymczasowego wyłączenia jego jawności. Tymczasem jeżeli już organ prowadzący postępowanie dojdzie do przekonania o konieczności ograniczenia dostępu do akt, to powinien na czas trwania takiego ograniczenia powstrzymać się

19 Wyrok ETPCz z 13 lutego 2001 roku, LEX nr 76284.

${ }^{20}$ Wyrok ETPCz z 13 lutego 2001 roku, w LEX nr 76285.

21 Zob. M. Wąsek-Wiaderek, Zasada..., s. 200.

22 Zob. § 121, 124 i 125 wyroku ETPCz (Wielka Izba) z 9 lipca 2009 roku w sprawie 11364/03 Mooren przeciwko Niemcom.

23 Zob. S. Steinborn, op.cit., s. 536. 
od stosowania środków ingerujących w prawa podstawowe, takie jak zatrzymanie (niem. Arrest) czy areszt tymczasowy (niem. Untersuchungshaft) ${ }^{24}$.

5. W polskim postępowaniu karnym dostęp do akt sprawy w toku postępowania przygotowawczego $\mathrm{w}$ związku ze stosowaniem tymczasowego aresztowania i wynikający stąd zasób informacji o podstawie dowodowej tego środka uregulowany jest w przepisach art. $156 \S 5 \mathrm{a}$, art. $249 \mathrm{a} \S 1$ pkt 2 oraz art. $250 \S 2 \mathrm{a}$ i $2 \mathrm{~b}$.

Według art. 249a $\S 1$ k.p.k. podstawę orzeczenia o zastosowaniu lub przedłużeniu tymczasowego aresztowania mogą tworzyć ustalenia poczynione na podstawie dowodów jawnych dla oskarżonego i jego obrońcy oraz dowodów z zeznań świadków, o których mowa w art. 250 § 2 b k.p.k., których nie ujawniono oskarżonemu i jego obrońcy. Stosownie zaś do art. $250 \S 2 b$ k.p.k., jeżeli zachodzi uzasadniona obawa zagrożenia życia, zdrowia albo wolności świadka lub osoby mu najbliższej, prokurator dołącza do wniosku o zastosowanie lub przedłużenie tymczasowego aresztowania dowody z zeznań świadka. $Z$ wymienionego przepisu wynika, że wskazanych w nim dowodów nie przedstawia się we wniosku w przedmiocie tymczasowego aresztowania, ale dołącza do tego wniosku w wyodrębnionym zbiorze dokumentów. Natomiast art. 156 §a k.p.k. zakłada wymóg udostępnienia oskarżonemu i jego obrońcy akt sprawy w części zawierającej treść dowodów wskazanych we wniosku o zastosowanie tymczasowego aresztowania, z wyłączeniem dowodów z zeznań świadków, o których mowa w art. 250 § 2 b k.p.k.

O włączeniu wymienionych dowodów do odrębnego zbioru prokurator nie informuje oskarżonego i jego obrońcy. Nie wiedzą oni więc o tym, że prokurator wraz z wnioskiem o zastosowanie lub przedłużenie tymczasowego aresztowania przekazał do sądu także dowody inne niż przedstawione we wniosku. Tym samym oskarżony i jego obrońca nie mają świadomości, że podstawą tymczasowego aresztowania mogą być dowody, których prokurator im nie ujawnił, i których nie przedstawił w rzeczonym wniosku.

Z art. 249a § 1 pkt 2 k.p.k. wynika, że sąd aresztowy może uczynić podstawą faktyczną decyzji w przedmiocie tymczasowego aresztowania okoliczności wynikające $\mathrm{z}$ zawartych $\mathrm{w}$ aktach dowodów, których nie ujawniono oskarżonemu i jego obrońcy. Będą one zatem podstawą do dokonywania ustaleń odnośnie do występowania przesłanki ogólnej i szczególnej tymczasowego aresztowania, określonych w art. $249 \S 1$ i $258 \S 1$ k.p.k. Podstawą tymczasowego aresztowania mogą być wszak dowody z zeznań świadka, o których mowa w art. 250 § 2b k.p.k., mimo że nie zostały ujawnione oskarżonemu i jego obrońcy.

Przepis art. 249a $§ 2$ k.p.k. zobowiązuje sąd do uwzględniania z urzędu także okoliczności, których prokurator nie ujawnił oskarżonemu i jego obrońcy, ale tylko korzystnych dla oskarżonego. W takim wypadku sąd, uprzedzając o tym prokuratora, ujawnia te okoliczności na posiedzeniu, co umożliwia oskarżonemu

${ }^{24}$ Zob. wyrok z 19 stycznia 2006 roku, sygn. 2 BvR 1075/05; podobnie w wyroku z 11 lipca 1994 roku, sygn. 2 BvR 777/94. 
obronę, a prokuratorowi ustosunkowanie się do tych okoliczności. Obrońca może zaś zwrócić sądowi uwagę na znajdujące się w aktach sprawy dowody korzystne dla oskarżonego, które zostały pominięte przez prokuratora, o ile ma taką wiedzę. Jeżeli więc z zeznań świadka, których prokurator nie udostępnił oskarżonemu i jego obrońcy na podstawie art. 156 § 5a k.p.k. w zw. z art. 250 § 2b k.p.k., wynikają okoliczności korzystne dla oskarżonego, sąd obowiązany jest ujawnić je na posiedzeniu, uprzedzając o tym prokuratora.

Decyzję o zachowaniu w poufności przed oskarżonym i jego obrońcą dowodów, o których mowa w art. 249a $\S 1$ pkt 2 k.p.k., podejmuje prokurator, a nie sąd lub inny organ sądowy. Przepisy postępowania karnego nie przyznają zaś oskarżonemu prawa do zaskarżenia decyzji prokuratora.

6. Z przytoczonych przepisów prawa polskiego wynika, że w razie złożenia $\mathrm{w}$ toku postępowania przygotowawczego wniosku o zastosowanie albo przedłużenie tymczasowego aresztowania prokurator powinien ujawnić oskarżonemu i jego obrońcy wszystkie dowody będące podstawą orzeczenia sądu w tym przedmiocie. Prokurator może jednak odmówić ujawnienia tym uczestnikom dowodów, o których mowa w art. 249a $\S 1$ pkt 2 k.p.k., nie informując ich o tym. Wymienionym uczestnikom nie udostępnia się bowiem dowodów z zeznań świadka, jeżeli zachodzi uzasadniona obawa zagrożenia życia, zdrowia albo wolności świadka lub osoby mu najbliższej. W takim wypadku prokurator nie przedstawia rzeczonych dowodów we wniosku o zastosowanie tymczasowego aresztowania, ale dołącza je do tego wniosku w wyodrębnionym zbiorze dokumentów. O tym, że poza dowodami opisanymi we wniosku przedstawianemu sądowi są także inne dowody, prokurator nie informuje oskarżonego i jego obrońcy. O występowaniu takich dowodów i przekazaniu ich do sądu wraz z wnioskiem o zastosowanie tymczasowego aresztowania oskarżony i jego obrońca mogą się dowiedzieć, jedynie gdy dotyczą one okoliczności korzystnych dla oskarżonego (co w praktyce nie wchodzi w rachubę), gdyż wtedy sąd obowiązany jest z urzędu uwzględnić te okoliczności, uprzedzając o tym prokuratora. Oskarżony i jego obrońca nie mają możliwości zakwestionowania decyzji prokuratora o zachowaniu w tajemnicy dowodów, o których mowa w art. 249a § 1 pkt 2 k.p.k., ponieważ nie przyznano im prawa do złożenia zażalenia w tej kwestii.

Zachowanie w tajemnicy przed oskarżonym $\mathrm{i}$ jego obrońcą niektórych dowodów mających znaczenie dla tymczasowego aresztowania oskarżonego pozostaje w sprzeczności z przedstawionymi wcześniej poglądami przedstawicieli doktryny prawa karnego procesowego oraz ze stanowiskiem Trybunału Konstytucyjnego wyrażonym w wyroku z dnia 3 czerwca 2008 roku, K 42/07, którego istotą było podkreślenie, że jawne dla oskarżonego i jego obrońcy mają być materiały (dowody) będące podstawą orzeczenia o zastosowaniu lub przedłużeniu tymczasowego aresztowania, niezależnie od tego, czy są przedstawione we wniosku, czy jedynie dołączone do niego. Jest sprzeczne także z ugruntowanym stanowiskiem ETPCz, według którego materiały (dowody) ważne dla zastosowania lub utrzy- 
mania tymczasowego aresztowania oraz oceny legalności stosowania tego środka należy udostępnić we właściwy sposób oskarżonemu i jego obrońcy ${ }^{25}$. Jeszcze raz należy powiedzieć, że Trybunał w Strasburgu nie nakazuje ujawnienia oskarżonemu i jego obrońcy całości materiałów uzasadniających tymczasowe aresztowanie i dopuszcza możliwość, że dostępu do pewnych materiałów obrona może nie uzyskać. Jednak konsekwentnie wyklucza dopuszczalność limitowania dostępu do dowodów istotnych dla uzasadnienia podejrzenia popełnienia przestępstwa i tym samym relewantnych do zastosowania tymczasowego aresztowania ${ }^{26}$.

Również według dyrektywy 2012/13/UE zasadą jest udostępnianie oskarżonemu i jego obrońcy dowodów mających istotne znaczenie dla skutecznego zakwestionowania legalności tymczasowego aresztowania. Dyrektywa dopuszcza jednak możliwość odmówienia dostępu do niektórych dowodów pod kilkoma warunkami. Po pierwsze, odmowę dostępu do części materiałów śledztwa należy traktować jako wyjątek od zasady jawności tych materiałów, co wymaga ścisłego i rygorystycznego interpretowania przesłanki wyłączenia tych materiałów, którą jest „poważne zagrożenie życia lub praw podstawowych innej osoby” oraz „bezwzględna konieczność ochrony ważnego interesu publicznego". Po drugie, odmowa dostępu do części dowodów nie może naruszać „prawa do rzetelnego procesu sądowego”, rozumianego zgodnie z art. 6 EKPC i orzecznictwem ETPCz. Po trzecie, decyzja o odmowie dostępu do niektórych materiałów śledztwa powinna być podjęta przez organ sądowy lub podlegać zaskarżeniu do sądu ${ }^{27}$. Po czwarte, oskarżony i jego obrońca muszą być poinformowani o zachowaniu w poufności niektórych dowodów.

Oceniając polskie regulacje proceduralne dotyczące dostępu do ,akt aresztowych" przez pryzmat dyrektywy 2012/13/UE, należy stwierdzić, że nie spełniają one warunków określonych w tej dyrektywie. Przepisy prawa polskiego dopuszczają bowiem możliwość oparcia decyzji sądu o zastosowaniu

25 Zob. M.A. Nowicki, Wokót Konwencji europejskiej. Komentarz do Europejskiej Konwencji Praw Człowieka, Warszawa 2017, s. 484-485 i cytowane tam orzecznictwo ETPCz.

${ }^{26}$ Na wymienioną okoliczność wskazał Rzecznik Praw Obywatelskich w piśmie do Ministra Sprawiedliwości z dnia 7 czerwca 2017 roku, II.511.733.2016.MM.

27 Według K. Eichstaeda ([w:] Kodeks postępowania karnego. Komentarz, t. 1, red. D. Świecki, Warszawa 2018, s. 924,) „decyzja prokuratora jest poddana kontroli w tym sensie, że w sytuacji, gdy sąd uzna, że w realiach danej sprawy nie zachodziły podstawy do utajnienia zeznań świadka z uwagi na uzasadnioną obawę niebezpieczeństwa dla życia, zdrowia lub wolności świadka lub osoby dla niego najbliższej, dowód z zeznań tego świadka będzie mógł stanowić podstawę wniosku o zastosowanie lub przedłużenie tymczasowego aresztowania tylko wówczas, gdy został ujawniony podejrzanemu i jego obrońcy". Nawet jeżeli pogląd ten uzna się za trafny, nie zmienia to faktu, że przepisy postępowania nie przyznają oskarżonemu prawa do zaskarżenia decyzji prokuratora o „utajnieniu” przed oskarżonym i jego obrońcą zeznań takiego świadka i przekazaniu ich do sądu wraz z wnioskiem w przedmiocie tymczasowego aresztowania w osobnym zbiorze, o którym mowa w art. $250 \S 2$ b k.p.k. 
lub przedłużeniu tymczasowego aresztowania na dowodach mających istotne znaczenie dla podjęcia takiej decyzji, które nie zostały ujawnione oskarżonemu i jego obrońcy. Konsekwencją takiego uregulowania jest pozbawienie tych uczestników możliwości kwestionowania dowodów przedstawionych sądowi przez prokuratora, relewantnych dla pozbawienia wolności oskarżonego. Powoduje to, że postępowanie sądowe $\mathrm{w}$ przedmiocie tymczasowego aresztowania pozbawione jest równości broni, a tym samym jest nierzetelne ${ }^{28}$.

Ponadto oskarżony i jego obrońca nie są informowani o zachowaniu w poufności niektórych dowodów, a tym samym pozbawieni możliwości zaskarżenia decyzji prokuratora do sądu. Zresztą przepisy postępowania nie przewidują uprawnienia oskarżonego do zaskarżenia decyzji prokuratora o zachowaniu w poufności części dowodów ważnych dla tymczasowego aresztowania, o których mowa w art. 249a $\S 1$ pkt 2 k.p.k., a tym bardziej uregulowania, że taką decyzję podejmuje sąd, a nie prokurator.

Uregulowanie zezwalające na odmówienie udostępnienia oskarżonemu i jego obrońcy zeznań świadka, jeżeli zachodzi uzasadnione zagrożenie życia, zdrowia albo wolności świadka lub osoby mu najbliższej, nie zawiera też warunków (ograniczeń) w postaci „wyjątkowego wypadku” i „nienaruszania prawa do rzetelnego procesu sądowego” oraz „poważnego zagrożenia” określonego dobra prawnego.

W piśmiennictwie wskazuje się, że pozbawienie oskarżonego lub jego obrońcy dostępu do dowodów uzasadniających podstawy stosowania tymczasowego aresztowania jest nieproporcjonalnym ograniczeniem zasady prawa do obrony oraz zasady równości broni ${ }^{29}$. W związku z tym standard stosowania tymczasowego aresztowania jest znacznie niższy niż pozostałych środków zapobiegawczych ${ }^{30}$.

Niezgodność omówionych przepisów prawa polskiego z dyrektywą 2012/ 13/UE powoduje możliwość powołania się na przepis art. 91 ust. 3 Konstytucji RP, stosownie do którego ,jeżeli wynika to z ratyfikowanej przez Rzeczpospolitą Polską umowy konstytuującej organizację międzynarodową, prawo przez nią stanowione jest stosowane bezpośrednio, mając pierwszeństwo w przypadku kolizji z ustawami”. Wymieniony przepis odnosi się bowiem między innymi do dyrektyw unijnych. Mimo że akty prawa stanowionego przez Unię Europejską nie zostały przez Konstytucję nazwane wprost „źródłami prawa powszechnie obowiązującego", status, jaki nadała tym aktom Konstytucja, pozwala na zaliczenie ich do katalogu takich źródeł ${ }^{31}$.

28 Por. K. Boratyńska, [w:] Kodeks postępowania karnego. Komentarz, red. A. Sakowicz, Warszawa 2018, s. 672.

29 Zob. W. Hermeliński, B. Nita-Światłowska, Kilka uwag o prawie do obrony w związu z nowelizacją Kodeksu postępowania karnego z 2016 r., „Palestra” 2016, nr 9, s. 22.

30 Zob. S. Waltoś, P. Hofmański, Proces karny. Zarys systemu, Warszawa 2016, s. 441.

31 Por. wyrok TK z 1 grudnia 1998 roku, K 21/98, OTK 1998, nr 7, poz. 116. 


\title{
STANDARD OF ACCESS TO INFORMATION ABOUT THE EVIDENTIAL BASE OF PROVISIONAL DETENTION IN EUROPEAN UNION AND POLISH LAW
}

\begin{abstract}
Summary
The author analyses whether the currently binding Polish regulations of the Code of Criminal Procedure concerning access to detainees' files comply with the provisions of Directive 2012/13/ EU of the European Parliament and of the Council of 22nd May 2012 on the right to information in criminal proceedings. Assessing Polish regulations, the author concludes that they do not meet the requirements laid down in the Directive. The provisions of Polish law admit the possibility of making a decision on the imposition or prolongation of detention on remand by a court based on evidence that is significant for taking this decision but has not been revealed to the accused and his counsel for the defence. As a result, a suspect and his lawyer are deprived of the possibility of challenging evidence submitted by the prosecutor. This makes the proceedings concerning detention on remand stripped of the equality of arms, and thus they are not fair.
\end{abstract}

Keywords: criminal procedure, equality of arms, remand/pre-trial detention, access to preparatory proceedings files

\section{BIBLIOGRAFIA}

Gronowska B., Wyrok Europejskiego Trybunału Praw Człowieka w Strasburgu z dnia 25 czerwca 2002 r. w sprawie Migoń przeciwko Polsce (dot. gwarancji procesowych dla osoby tymczasowo aresztowanej), Prok. i Pr 2002, nr 12.

Hermeliński W., Nita-Światłowska B., Kilka uwag o prawie do obrony w związku z nowelizacja Kodeksu postępowania karnego z 2016 r., „Palestra” 2016, nr 9.

Hofmański P., Dostęp do akt postępowania przygotowawczego. Uwagi na tle nowelizacji art. 156 k.p.k., [w:] Węzłowe problemy prawa karnego, kryminologii i polityki kryminalnej. Księga pamiątkowa ofiarowana Profesoirowi Andrzejowi Markowi, red. V. Konarska-Wrzosek, J. Lachowski, J. Wójcikiewicz, Warszawa 2010.

Kardas P., Standard rzetelnego procesu a prawo wgladu do akt sprawy w postępowaniu w przedmiocie tymczasowego aresztowania, czyli historia jednej nowelizacji, Prok. i Pr. 2010, nr 1-2.

Kardas P., Uprawnienia obrony do wgladu $w$ akta postępowania przygotowawczego $w$ toku procedury habeas corpus. Rzecz o obstrukcji organów wymiaru sprawiedliwości, CzPKiNP 2009, z. 3 .

Kardas P., Z problematyki dostęu do akt sprawy w postępowaniu o wyrażenie zgody na pociagnięcie sędziego do odpowiedzialności karnej, [w:] Nauki penalne wobec wspótczesnej przestępczości. Księga jubileuszowa z okazji 70. rocznicy urodzin Profesora Andrzeja Gaberle, red. K. Krajewski, Warszawa 2007.

Kardas P., Wiliński P., O niekonstytucyjności odmowy dostępu do akt sprawy w postepowaniu w przedmiocie tymczasowego aresztowania, „Palestra” 2008, $\mathrm{nr} 7-8$.

Karlik P., Stosowanie środków zapobiegawczych w projekcie nowelizacji kodeksu postępowania karnego, [w:] Kontradyktoryjność w polskim procesie karnym, red. P. Wiliński, Warszawa 2013.

Kodeks postępowania karnego. Komentarz, red. A. Sakowicz, Warszawa 2018.

Kodeks postępowania karnego. Komentarz, t. 1, red. D. Świecki, Warszawa 2018.

Nowicki M.A., Wokót Konwencji europejskiej. Komentarz do Europejskiej Konwencji Praw Człowieka, Warszawa 2017. 
Rusinek M., O dostepie do akt postępowania przygotowawczego de lege ferenda, CzPKiNP 2008, z. 2.

Skorupka J., Granice prawa do obrony i działań obrończych w procesie karnym, [w:] Etyka adwokacka a kontradyktoryjny proces karny, red. J. Giezek, P. Kardas, Warszawa 2015.

Skorupka J., W kwestii dostepu tymczasowo aresztowanego do wniosku w przedmiocie tymczasowego aresztowania oraz do akt sprawy w postępowaniu przygotowawczym na marginesie orzeczeń sąów powszechnych, „Palestra” 2008, nr 7-8.

Sokołowska D., Konwencyjny $i$ konstytucyjny standard rzetelnego procesu w ramach postępowania typu habeas corpus $w$ świetle uregulowań kodeksu postepowania karnego, „Internetowy Przegląd Prawniczy TBSP UJ" 2016, nr 2.

Steinborn S., Dostęp obrony do akt postępowania przygotowawczego w zwiazku z procedura habeas corpus - standard strasburski i jego realizacja w polskim procesie karnym, [w:] Problemy wymiaru sprawiedliwości karnej. Księa jubileuszowa Profesora Jana Skupińskiego, red. A. Błachnio-Parzych, J. Jakubowska-Hara, J. Kosonoga, H. Kuczyńska, Warszawa 2013.

Tęcza-Paciorek A., Wróblewski K., Dostęp podejrzanego do akt postępowania w przedmiocie tymczasowego aresztowania, $\mathrm{PiP} 2010, \mathrm{nr} 5$.

Tęcza-Paciorek A., Wróblewski K., Skutki wyroku Trybunału Konstytucyjnego z dnia 3 czerwca 2008 r. sygn. akt K 42/07 dla realizacji prawa podejrzanego do obrony $w$ postepowaniu $w$ przedmiocie zastosowania tymczasowego aresztowania w świetle art. 156 \$ 5 a k.p.k., „Ius Novum" 2011, nr 3.

Waltoś S., Hofmański P., Proces karny. Zarys systemu, Warszawa 2016.

Wąsek-Wiaderek M., Dostęp do akt sprawy oskarżonego tymczasowo aresztowanego i jego obrońcy w postępowaniu przygotowawczym - standard europejski a prawo polskie, „Palestra” 2003, nr 3-4.

Wąsek-Wiaderek M., Zasada równości stron w polskim procesie karnym w perspektywie porównawczej, Kraków 2003.

Wiliński P., Odmowa dostępu do akt sprawy w postępowaniu przygotowawczym, Prok. i Pr. 2006, nr 11.

Przegląd Prawa i Administracji CXX, 2020, cz. 1 i 2

(C) for this edition by CNS 